\title{
Space-Time Variability of Summer Hydroclimate in the U.S. Prairie Pothole Region 0
}

\author{
Benjamin D. ABel, ${ }^{a}$ BALAJI RAJAgOPALAN, ${ }^{\mathrm{a}, \mathrm{b}}$ AND ANDREA J. RAY ${ }^{\mathrm{c}}$

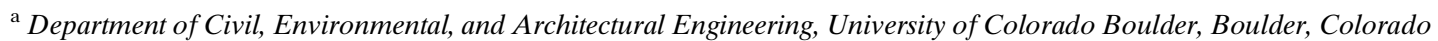 \\ ${ }^{\mathrm{b}}$ Cooperative Institute for Research in Environmental Sciences, University of Colorado Boulder, Boulder, Colorado \\ ${ }^{\mathrm{c}}$ Physical Sciences Laboratory, National Oceanic and Atmospheric Administration, Boulder, Colorado
}

(Manuscript received 9 February 2021, in final form 18 December 2021)

\begin{abstract}
The Prairie Pothole Region (PPR) experiences considerable space-time variability in temperature and precipitation, and this variability is expected to increase. The PPR is sensitive to this variability-it plays a large role in the water availability of the region. Thousands of wetlands in the region, sometimes containing ponds, provide habitats and breeding grounds for various species. Many wildlife management decisions are planned and executed on subseasonal-toseasonal time scales and would benefit from knowledge of seasonal conditions at longer lead times. Therefore, it is important to understand potential driving mechanisms and teleconnections behind space-time climate variability in the PPR. We performed principal component analysis on summer precipitation of the southeastern PPR (SEPPR) to determine the leading principal components (PCs) of variability. These PCs were used to establish teleconnections to large-scale climate variables and indices. They were also used to determine potential mechanisms driving the precipitation variability. There were teleconnections to Pacific and Atlantic Ocean sea surface temperatures (SST) resembling the Pacific decadal oscillation and El Niño-Southern Oscillation, low 500-hPa heights over the western United States, and the Palmer drought severity index over the SEPPR. A large-scale low pressure region over the northwestern United States and a pattern like the Great Plains low-level jet, observed in the 500- and 850-hPa heights and winds, are a potential mechanism of the precipitation variability by increasing precipitation during wet PC1 years. These findings can inform management actions to maintain and restore wildlife habitat and the resources used for those actions in the PPR.
\end{abstract}

KEYWORDS: Precipitation; Summer/warm season; Empirical orthogonal functions; Principal components analysis; Climate variability

\section{Introduction}

The Prairie Pothole Region (PPR) encompasses nearly $800000 \mathrm{~km}^{2}$ in the United States and Canada (Smith et al. 1964) and is the largest wetland complex in North America (van der Valk 2005) with over 2.5 million ponds (Dahl 2014), also known as potholes. The ponds range in permanence from ephemeral to persistent. Over $50 \%$ of the North American duck population breeds in this important habitat during spring and early summer (Batt et al. 1989). Waterfowl and other species depend on these wetlands to survive (Dyke et al. 2015; Steen et al. 2014; Balas et al. 2012; Batt et al. 1989; Kantrud et al. 1989). These ponds also provide floodwater storage (Gleason et al. 2011; Gleason and Tangen 2008).

Two of the most significant threats to the PPR's wetlands are 1) climate variability and change and 2) agricultural landuse and land-cover change. Land cover/land use and climate are inherently linked-change in land cover/land use can

\footnotetext{
O) Supplemental information related to this paper is available at the Journals Online website: https://doi.org/10.1175/EI-D-21-0004.s1.
}

Corresponding author: Benjamin D. Abel, benjamin.abel@ colorado.edu

Earth Interactions is published jointly by the American Meteorological Society, the American Geophysical Union, and the Association of American Geographers. influence changes in climate and vice versa (Sleeter et al. 2018). In the last half century, agricultural land use in the PPR has shifted. In the 1980s, there was a large swing toward restoring natural landscape from agriculture after the Conservation Reserve Program was established. In the 2000s, natural landscapes have again decreased, attributed to expansion of agriculture (Sleeter et al. 2018), especially corn, oil and gas development, and draining of wetlands for agricultural land (Yocum and Ray 2019). Increased irrigation can cause a reduction in surface air temperature in its vicinity (Diffenbaugh 2009; Lobell et al. 2009; Sacks et al. 2009). Increases in precipitation downwind of largely irrigated croplands has also been observed (DeAngelis et al. 2010). Therefore, land-cover changes can affect the climate signal and also the climate variability over a region depending on how widespread the changes are.

Previous studies accentuate the importance and potential impact of these threats (McKenna et al. 2017; McCauley et al. 2015; Anteau et al. 2016). These threats impact managers' decisions on various conservation strategies to maintain and improve habitat. These strategies are intended to maximize waterfowl nesting success and are timed to avoid adversely affecting migratory birds (U.S. Fish and Wildlife Service 2015). Many plans are developed and decisions are made early in the year, such as habitat restoration and revegetation, and would take advantage of knowledge of seasonal variability. Resource managers in the region are aware that subseasonal to seasonal climate information is important in their planning and decision-making on this time scale (Yocum and 
Ray 2019). Examples include predicting wildlife numbers for hunting quotas, informing decisions about prescribed burning, and taking actions to manage invasive plant species. However, they report that climate information at this time scale is limited or does not meet their needs to support these and other decisions (Yocum and Ray 2019).

In the PPR, temperature and precipitation vary widely spatially and temporally (Mushet 2016; Millett et al. 2009; Johnson et al. 2004; Rosenberry 2003). Its midcontinent location exposes it to air masses of a wide variety of temperature and moisture content. In the summer, competing continental polar, maritime polar, and maritime tropical air masses contribute to this variability (Bryson and Hare 1974; Brunnschweiler 1952). A stark example of variability occurred in the early 2010s when the Missouri River basin flooded in 2011 and then experienced drought in the following year (Conant et al. 2018). Historical climate analysis and model projections show the prairie wetlands are sensitive to climate variability (Johnson and Poiani 2016; Johnson et al. 2010, 2005, others); these varying annual weather conditions partially determine water availability in the region (Hayashi et al. 2016; LaBaugh et al. 2016; Liu and Schwartz 2012) and occurrence and extent of the ponds (Huang et al. 2011; Sorenson et al. 1998).

There have been some notable changes in the historical PPR climate since 1900. Millett et al. (2009) found that while annual temperatures and precipitation have generally increased, there are more nuanced spatial and temporal changes. The minimum daily temperature has warmed while the maximum has cooled. The prominent east-west precipitation gradient (see Millett et al. 2009, their Fig. 3) steepened, with the west receiving less annual rainfall and the east receiving more. Seasonally, the precipitation increase happened mostly during winter, spring, and autumn (Ballard et al. 2014). Winter temperatures warmed after the 1980s, and spring temperatures warmed until the 1980s before starting to cool. The summers in the early twentieth century were slightly cooler. Thus, to inform management, it is important to understand and predict the temporal and spatial temperature and precipitation variability because of the roles they play in determining regional water availability and thus the availability of wetland habitat.

There is a body of literature examining summer climate variability and its teleconnections in the Great Plains (Ting and Wang 1997; Ruiz-Barradas and Nigam 2005; Capotondi and Alexander 2010; Flanagan et al. 2018, 2019; and others), of which the southeastern PPR is a part, although these studies do not focus specifically on the southeastern PPR. Studies of climate and pond variability focused on the PPR have targeted climate change impacts (e.g., Niemuth et al. 2010; Sorenson et al. 1998; Larson 1995). Larson (1995) examined pond-count variability accountable to precipitation and temperature. Sorenson et al. (1998) found a strong correlation between pond counts and Palmer drought severity index (PDSI). Wet area of about 40000 wetland basins sampled in May from 1988 to 2007 were assessed spatially and temporally in the U.S. PPR by Niemuth et al. (2010) identifying high variability in wetness. A study focused on the PPR in Canada analyzed the variability of drought and wet seasons
(May-August) to establish large-scale connections and mechanisms (Shabbar et al. 2011). However, similar analysis has not been performed on the southeastern PPR - the portion of the PPR in the United States. These studies do not provide information for predictions in the near term.

To understand climate variability of the PPR, it is important to understand its potential driving mechanisms and largescale teleconnections. We address this need by employing a novel method to connect the summer precipitation variability in the southeastern PPR to large-scale teleconnections and potential driving mechanisms thereby identifying them. We focus on climate variability on a subseasonal-to-seasonal scale due to its influence on management decisions and potential for predictability (Yocum and Ray 2019; White et al. 2017). Further, our analysis overlaps with the time period and regions used in the U.S. Fish and Wildlife Service Waterfowl Breeding Population and Habitat Survey, allowing our results to assist PPR managers because they frequently use the survey data to assist in developing conservation strategies. The results of our analysis can ultimately inform predictive studies as has already been done in Abel et al. (2020).

We chose summer rainfall because it contributes approximately half of the annual precipitation in the southeastern PPR (Vecchia 2008; Rosenberry 2003). Our own analysis corroborates this (see section 4). This rainfall sustains existing wetlands and therefore waterfowl nesting habitat. Ponds receive their major inflows from snowmelt, which has contributed almost $90 \%$ of surface runoff in some years (LaBaugh et al. 2018; Pomeroy et al. 1998), and summer precipitation (Winter 2000), mainly due to the low hydraulic conductivity of the glacial deposits that make up the bulk of the top layers of soil (Hayashi et al. 2016). Even a small increase in annual precipitation can result in a large increase in water to wetlands (Hayashi et al. 2016). In one representative wetland, pond depth sharply increased during snowmelt season followed by a period of sustained depth due to summer precipitation (Hayashi et al. 2016). The highest amount of evapotranspiration in the southeastern PPR occurs during the summer, and without ample summer precipitation, a loss of flooded wetland habitat can occur. This loss reduces renesting propensity and brood survival (Howerter et al. 2014).

We begin by describing the study region and the datasets used. We then discuss the novel methods used in our analysis. The results discuss some observations about southeastern PPR precipitation then describe large-scale climate teleconnections and potential mechanisms driving summer precipitation variability. Last, we discuss the meaning and context of these novel results.

\section{Study region and data}

This study focuses on the southeastern PPR located within the United States (SEPPR; Fig. 1). Twenty-two climate divisions were chosen to represent the SEPPR because they were spatially coincident (Fig. 1). Temporally concurrent and spatially conterminous data were retrieved from various sources for this study, and these datasets are summarized in Table 1. 


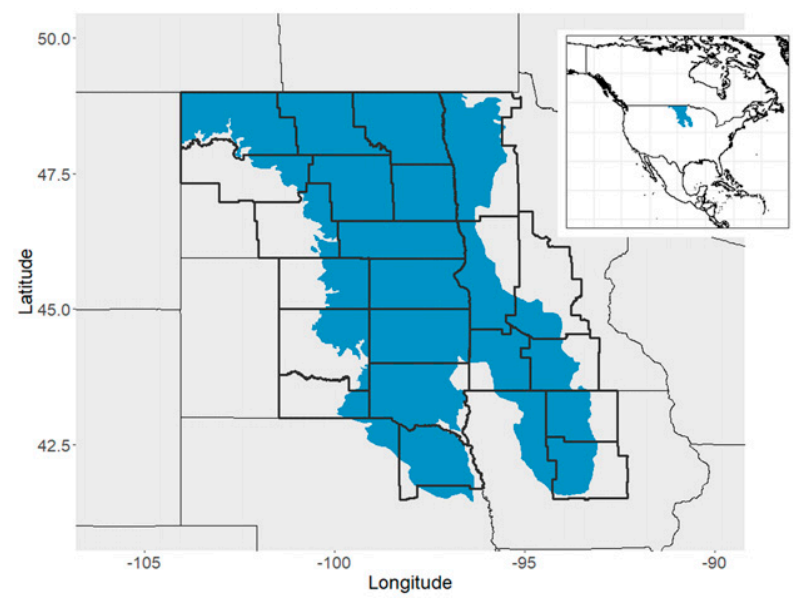

FIG. 1. Map of the north-central United States showing the SEPPR (in blue) and the U.S. CDs (thick outlines) used in this study. The inset shows the location of the SEPPR within North America.

We retrieved monthly precipitation data spatially averaged by climate division (CD), gridded sea surface temperature anomaly data (SST), gridded 500-hPa height anomaly data, and PDSI. For these analyses, June-September (herein, "summer"; JJAS) is used for summer seasonal averages for all data. September is included because it is part of the peak months of precipitation in the SEPPR (more discussion on this is in section 4).

Data to plot composite maps of summer averages of 500and $850-\mathrm{hPa}$ heights/winds, SST, and PDSI anomalies for specific years were generated by the National Oceanic and Atmospheric Administration's (NOAA) Physical Sciences Laboratory (PSL) Interactive Climate Analysis plotting tool using the NCEP-NCAR reanalysis and other datasets. The climatology used for these composite maps was 1981-2010.

\section{Methods}

\section{a. Principal component analysis of summer precipitation}

Principal component analysis (PCA), sometimes referred to as empirical orthogonal function (EOF) analysis when performed on meteorological data (Jolliffe and Cadima 2016), finds vectors [principal components (PCs)] through a multivariate (e.g., $n$ observations of $p$ variables) dataset that collectively explains the total variance within the dataset (von Storch 1999; Jolliffe 2002). The vectors are linear functions of the original variables and are orthogonal to one another. The method of locating vectors is such that the PCs are arranged from highest (the first PC) to lowest (the last PC) variance explained-the first $\mathrm{PC}$ is the linear function explaining the maximum possible variance, the second $\mathrm{PC}$ is the linear function explaining the maximum possible variance with the restraint of being orthogonal to the first $\mathrm{PC}$, and so on. The amount of variance explained by each PC is contained in the eigenvalues and can be visualized by a scree plot (Cattell
1966; Fig. S1 in the online supplemental material). There are the same number of PCs as there are variables in the original data. PCA is, therefore, a dimension-reducing technique because a subset of PCs that explain a user-defined amount of variance can be used for analysis purposes. There are numerous methods to choose the number of PCs to retain for analysis, but it is ultimately a subjective choice that is dictated by the data and purpose of analysis. Further, when using PCA on data with temporal and spatial components, such as daily precipitation at various weather stations, the resulting PCs retain these attributes allowing for temporal and spatial analysis via PC scores and eigenvectors, respectively.

PCA was performed on the CD precipitation data averaged temporally by summer-a multivariate dataset consisting of 123 years of summer precipitation observations for 22 CDs. From the resulting 22 PCs, we chose the top two for analysis. More discussion of our decision to use two PCs is in section $4 \mathrm{~b}$, as well as in the online supplemental material: "PCA of summer average precipitation-Scree plot" section and Fig. S1.

Signs on PC scores are arbitrary in relation to the original data (in our case the precipitation data). To determine how the PC's temporal trend relates to the original data, the correlation between the two can be calculated. A positive correlation indicates the trend of the $\mathrm{PC}$ is the same as the original data, whereas a negative correlation indicates the opposite. In our case, there was a positive correlation between $\mathrm{PC} 1$ and the precipitation data, meaning that the highest $\mathrm{PC}$ scores are each high-precipitation (wet) years; the lowest PC scores are each low-precipitation (dry) years. The trend of the precipitation data is therefore the same as the PC's temporal trend.

\section{b. Using PCA to find teleconnections to large-scale climate and potential mechanisms driving variability}

Teleconnections to large-scale climate and potential mechanisms driving variability were determined using results from PCA. PC1 and PC2 scores were correlated with each grid point native to the SST anomalies, 500-hPa height anomalies, and PDSI data to generate correlation maps. The locations with highest-magnitude correlation represent regions with a statistical, and therefore most likely a physical, connection between precipitation variability and the correlated climate variable. We also performed a regression analysis in a similar manner (linear model fitted at each grid point) and verified that regions with significant regression coefficients (at 95\%) coincide with the high-magnitude correlations. Plots of these results can be seen in Figs. S2 and S3 of the online supplemental material.

We chose to correlate PC scores with the aforementioned variables to represent primary subsystems of the Earth system-the lithosphere via PDSI, the atmosphere via 500- and $850-\mathrm{hPa}$ heights and winds, and the hydrosphere via SSTs. Although PDSI uses temperature and, more notably, precipitation information in its calculation, we use it as a surrogate for land because soil moisture data are lacking, both temporally and spatially (Quiring et al. 2016). In addition, PDSI is 
TABLE 1. Datasets used in this study.

\begin{tabular}{|c|c|c|c|c|}
\hline Variable(s) & Dataset description & Spatial resolution & $\begin{array}{c}\text { Years } \\
\text { available }\end{array}$ & $\begin{array}{l}\text { Months } \\
\text { covered }\end{array}$ \\
\hline \multicolumn{5}{|c|}{ Precipitation analysis and $P C A$} \\
\hline Precipitation & $\begin{array}{l}\text { NOAA National Centers for } \\
\text { Environmental Information } \\
\text { (NCEI) nClimDiv (Vose et al. } \\
\text { 2014); derived from } \\
\text { observations }\end{array}$ & U.S. CDs & $1895-2017$ & All \\
\hline \multicolumn{5}{|c|}{ Correlation maps } \\
\hline SST anomalies & $\begin{array}{l}\text { Kaplan et al. (1998) and Reynolds } \\
\text { and Smith (1994) from the } \\
\text { International Research Institute } \\
\text { (IRI) Data Library; derived } \\
\text { from observations }\end{array}$ & $\begin{array}{l}5^{\circ} \times 5^{\circ} \text { grid } \\
87.5^{\circ} \mathrm{S}-87.5^{\circ} \mathrm{N} \\
27.5^{\circ}-22.5^{\circ} \mathrm{E}\end{array}$ & $1896-2017$ & JJAS \\
\hline $\begin{array}{l}\text { 500-hPa height } \\
\text { anomalies }\end{array}$ & $\begin{array}{l}\text { NOAA Climate Data Assimilation } \\
\text { System I (CDAS-1; Kalnay } \\
\text { et al. 1996) from IRI Data } \\
\text { Library; reanalysis data }\end{array}$ & $\begin{array}{l}2.5^{\circ} \times 2.5^{\circ} \text { grid } \\
\quad 90^{\circ} \mathrm{N}-90^{\circ} \mathrm{S}, 0-2.5^{\circ} \mathrm{W}\end{array}$ & 1949-2017 & JJAS \\
\hline PDSI & $\begin{array}{l}\text { Self-calibrated PDSI (Dai et al. } \\
\text { 2004) from NOAA/PSL Climate } \\
\text { Data Repository; derived from } \\
\text { observations }\end{array}$ & $\begin{array}{l}2.5^{\circ} \times 2.5^{\circ} \text { grid } \\
58.75^{\circ} \mathrm{S}-76.25^{\circ} \mathrm{N} \\
178.75^{\circ} \mathrm{W}-178.75^{\circ} \mathrm{E}\end{array}$ & $1850-2014^{\mathrm{a}}$ & JJAS \\
\hline \multicolumn{5}{|c|}{ Composite maps } \\
\hline $\begin{array}{l}\text { 500- and } 850-\mathrm{hPa} \\
\text { heights/winds }\end{array}$ & $\begin{array}{l}\text { NCEP-NCAR reanalysis monthly } \\
\text { means and other derived } \\
\text { variables (Kalnay et al. 1996) } \\
\text { from NOAA/PSL analysis and } \\
\text { plotting tools; reanalysis data }\end{array}$ & $\begin{array}{l}2.5^{\circ} \times 2.5^{\circ} \text { grid } \\
\quad 90^{\circ} \mathrm{N}-90^{\circ} \mathrm{S}, 0^{\circ}-357.5^{\circ} \mathrm{E}\end{array}$ & $1948-2017$ & JJAS \\
\hline SST & $\begin{array}{l}\text { NOAA Extended Reconstructed } \\
\text { SST V5 (Huang et al. 2017) } \\
\text { from NOAA/PSL analysis and } \\
\text { plotting tools; reanalysis data }\end{array}$ & $\begin{array}{l}2.0^{\circ} \times 2.0^{\circ} \text { grid } \\
88.0^{\circ} \mathrm{N}-88.0^{\circ} \mathrm{S} \\
0.0^{\circ}-358.0^{\circ} \mathrm{E}\end{array}$ & $1854-2020$ & JJAS \\
\hline PDSI & $\begin{array}{l}\text { PDSI (Dai et al. 2004) from } \\
\text { NOAA/PSL analysis and } \\
\text { plotting tools; derived from } \\
\text { observations }\end{array}$ & $\begin{array}{l}2.5^{\circ} \times 2.5^{\circ} \text { grid } \\
58.75^{\circ} \mathrm{S}-76.25^{\circ} \mathrm{N} \\
178.75^{\circ} \mathrm{W}-178.75^{\circ} \mathrm{E}\end{array}$ & $1870-2005$ & JJAS \\
\hline
\end{tabular}

${ }^{\mathrm{a}}$ Data to 2014 were available at publication.

widely used, and therefore land-use managers and other stakeholders in the SEPPR are familiar with it.

Potential mechanisms of variability were determined using extreme values (i.e., years) of PC1 and PC2 scores. Using quantiles, the years with the highest ( $>0.85$ quantile) and lowest $(<0.15$ quantile) values in the PC time series (1895-2017) were determined, resulting in four subsets of 19 years. Table 2 shows the high and low years for both PCs. Recall that high PC scores correspond to wet years and low PC values correspond to dry years. Composite fields of $500-$ and $850-\mathrm{hPa}$ height and wind anomalies, SSTs anomalies, and PDSI anomalies were then generated using PSL's Interactive Climate Analysis plotting tool for the wet (high PC) and dry (low PC) years. Note that the years used in the composites were restricted by the years available in the datasets (see Table 1). The composite maps for PC1 were then used to identify potential mechanisms responsible for precipitation variability. Composite maps for PC2 did not uncover new potential mechanisms, so they are left to the online supplemental material: Figs. S4 and S5. Composite fields of precipitable water anomalies and soil moisture anomalies were also plotted for PC1 and discussed (see the online supplemental material "Potential mechanisms driving variability-precipitable water and soil moisture" section and Figs. S6 and S7).

\section{Results}

\section{a. Summer precipitation in the SEPPR}

Before we examine PCA of summer precipitation, we make some observations of the CD precipitation (spatially averaged by $\mathrm{CD}$ and temporally averaged by month). In examining the monthly climatology using the most recent 30-year period (1981-2010), it is seen that there is a clear seasonal cycle for the SEPPR precipitation, with the maximum in June (Fig. 2, black line). Rosenberry (2003) also found that June was historically the wettest month at the Cottonwood Lake area in North Dakota. The 22 CDs (Fig. 2, gray lines) generally follow this trend, although some CDs receive higher precipitation in August than in July. The summer wet period extends 
TABLE 2. Wet and dry years determined from PC1 and PC2 scores used to generate summer composites.

\begin{tabular}{|c|c|c|c|}
\hline \multicolumn{2}{|c|}{$\mathrm{PC} 1$} & \multicolumn{2}{|c|}{$\mathrm{PC} 2$} \\
\hline Wet & Dry & Wet & Dry \\
\hline 1900 & 1898 & 1902 & 1904 \\
\hline 1901 & 1910 & 1906 & 1912 \\
\hline 1905 & 1917 & 1908 & 1916 \\
\hline 1914 & 1922 & 1915 & 1927 \\
\hline 1915 & 1929 & 1917 & 1928 \\
\hline 1928 & 1930 & 1919 & 1931 \\
\hline 1941 & 1931 & 1923 & 1935 \\
\hline 1944 & 1933 & 1929 & 1937 \\
\hline 1957 & 1934 & 1933 & 1941 \\
\hline 1962 & 1936 & 1934 & 1947 \\
\hline 1965 & 1958 & 1951 & 1954 \\
\hline 1968 & 1967 & 1960 & 1964 \\
\hline 1977 & 1970 & 1967 & 1971 \\
\hline 1986 & 1974 & 1979 & 1975 \\
\hline 1993 & 1976 & 1984 & 1980 \\
\hline 2005 & 1988 & 1992 & 1991 \\
\hline 2010 & 1989 & 2006 & 2000 \\
\hline 2014 & 2003 & 2010 & 2002 \\
\hline 2016 & 2012 & 2015 & 2012 \\
\hline
\end{tabular}

into September (Fig. 2), so we include September in our analysis of summer precipitation.

In general, over one-half of the precipitation within the SEPPR occurs during summer. During the period 1896-2017, summer precipitation in CDs ranged from $49.5 \%$ to $57.4 \%$ of the annual total (Fig. 3). This is why we chose to analyze the summer season.

\section{b. PCA of summer average precipitation}

The first two PCs explain $66.1 \%$ of summer precipitation variance (recall that this is derived from their eigenvalues), with the first explaining $54.3 \%$ and second explaining $11.8 \%$. Having this much variance explained in the first PC is uncommon for precipitation because of its innate variability. We acknowledge that some of the natural variability in the

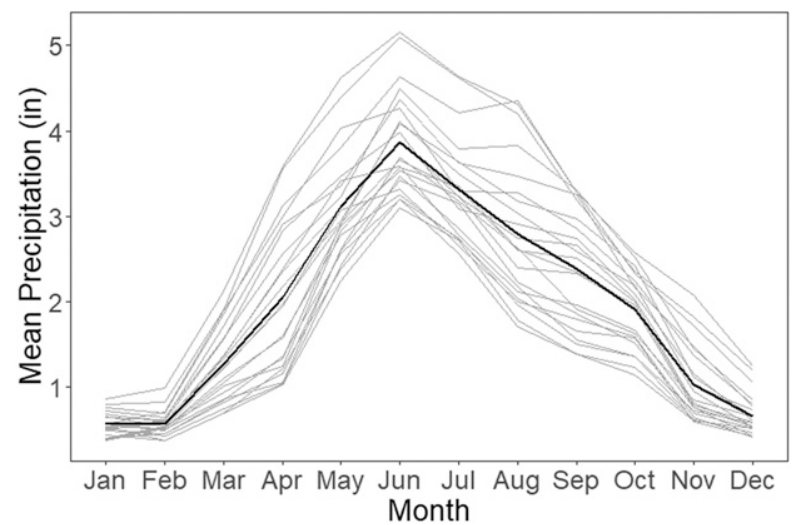

FIG. 2. Climatology (1981-2010) of the monthly precipitation for the SEPPR. Gray lines represent the $22 \mathrm{CDs}$ chosen to represent the SEPPR. The black line is the SEPPR spatial average.

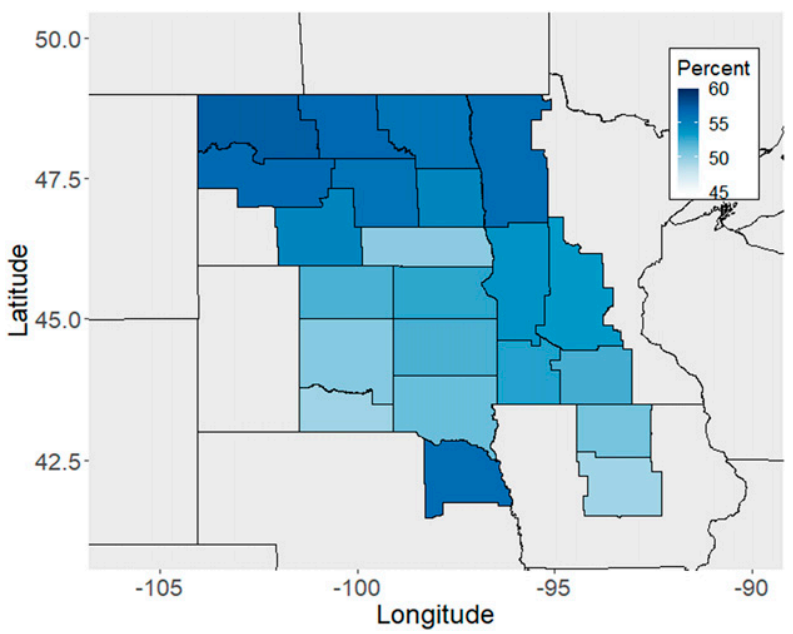

FIG. 3. Summer (JJAS) precipitation as a percentage of annual precipitation, by CD.

precipitation data may be averaged out by using the spatially averaged CD data and by temporally averaging over the summer. However, we used CD data because they have a long period of record and are well quality controlled. Also, the SEPPR is generally flat, so using the spatially averaged CDs is appropriate. It is common practice to examine the first two or three PCs in climate analysis because it is usually difficult to determine physical connections beyond these PCs. This was true for our analysis, as PC3 (not shown) explained only 7.8\% of the variance and did not show significant patterns or correlations. Thus, the first two PCs were used for analysis in this study.

Spatial loading (eigenvectors) and temporal PC scores of the first two PCs are shown in Fig. 4. Spatially, PC1 (Fig. 4a) displays a homogenous sign (all positive) with a small range of loadings (approximately from 0.16 to 0.23 ). This indicates a spatially homogeneous correlation between the wet or events across the SEPPR, as well as the dry ones. The second PC (Fig. 4b), however, has a distinct north-south dipole in its spatial loadings, indicating a heterogeneous correlation between the north and south SEPPR. Temporally, PC1 (Fig. 4c) shows a positive linear trend that is significant on a level of $p=$ 0.086 using the Cox and Stuart trend test (Cox and Stuart 1955). The trend in PC2 (Fig. 4d) is not significant.

\section{c. Large-scale climate teleconnections}

Maps of the correlation between the first two PC scores (Figs. 4c and d) and concurrent summer SST anomalies, 500$\mathrm{hPa}$ height anomalies, and PDSI values are shown in Figs. 5 and 6. PC1 shows highest correlation (magnitude about 0.4) to Atlantic Ocean SSTs and a smaller correlation (magnitude of $\sim 0.2$ ) to northern Pacific SSTs; there is a dipole in correlation values in both regions (Fig. 5a). The equatorial Pacific correlations resemble an El Niño-Southern Oscillation (ENSO) pattern, albeit the correlations are weak for the waters extending west from South America's coast. PC1 shows highest correlation (magnitude of $\sim 0.3$ ) with $500-\mathrm{hPa}$ 
(A)
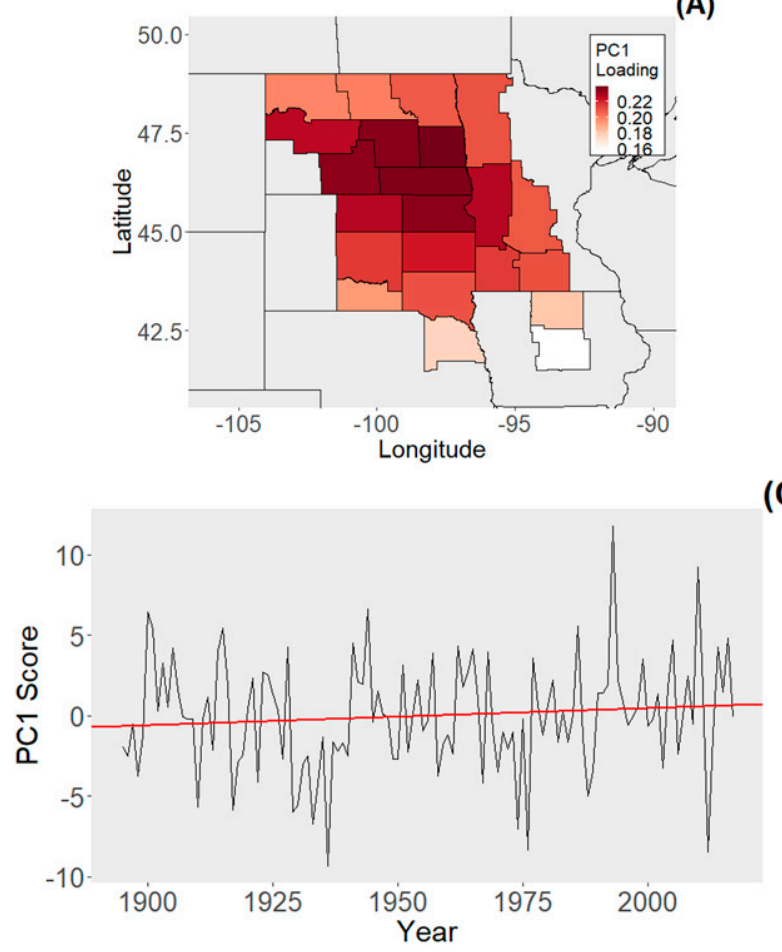

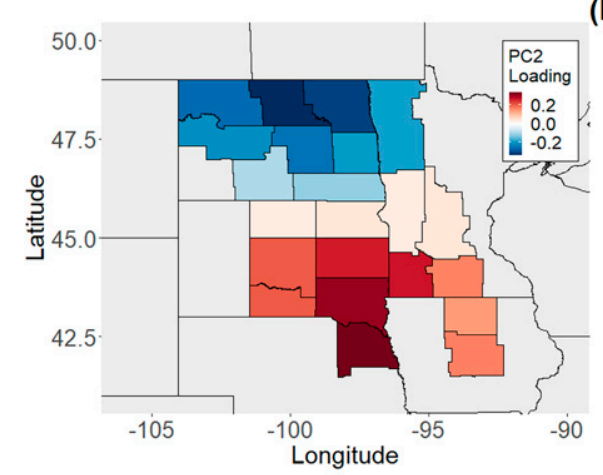

(B)

(C)

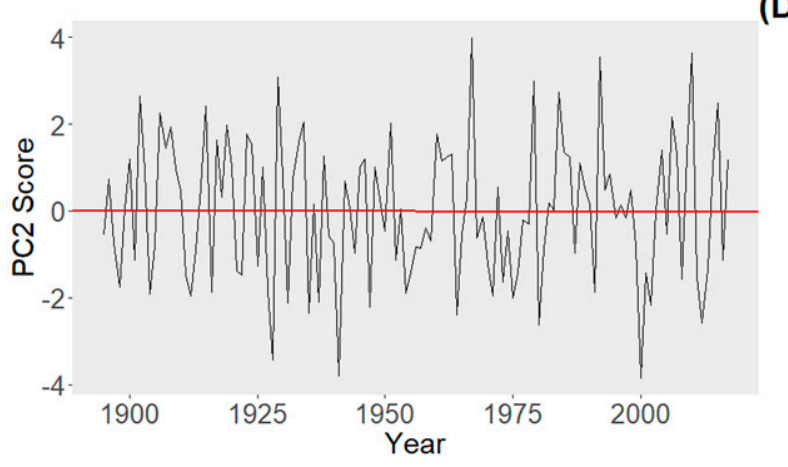

(D)

FIG. 4. Loadings (eigenvectors) and PC scores for PCA performed on CD-mean summer precipitation: spatial distributions of the eigenvectors for (a) PC1 and (b) PC2 and time series of (c) PC1 and (d) PC2 scores.

heights over the northwestern United States, Siberia, and the western Pacific Ocean (Fig. 5b). The highest correlation (magnitude between 0.4 and 0.6 ) between PC1 and PDSI is in the SEPPR (Fig. 5c). Positive correlations between PC1 and PDSI cover the United States west of the Appalachian Mountains (Fig. 5c). PC2 correlates most (magnitude between 0.1 and 0.4) with northern Pacific SSTs (Fig. 6a), Arctic 500-hPa heights (Fig. 6b), and central United States PDSI (Fig. 6c).

\section{d. Potential mechanisms driving variability}

Extreme wet and dry years (determined from extremes of PC1 scores) provide potential driving mechanisms as seen in Figs. 7 and 8 . The geopotential height and wind wetyear composites for PC1 (Figs. 7a and c) show an anomalous 500-hPa low over the northwestern United States and southcentral Canada. An anomalous low with associated anomalous cyclonic (counterclockwise) winds (Fig. 7a) provides moisture and a lifting mechanism conducive for the development of thunderstorms. Composites of $850-\mathrm{hPa}$ heights for PC1's wet years show anomalous low heights slightly east and south of the 500-hPa low (Fig. 7c). The 850-hPa winds (Fig. 7c) show a pattern like the Great Plains low-level jet (GPLLJ). The GPLLJ is a region of low-level, southerly flow from the Gulf of Mexico that brings moisture northward over the Midwest to the central United States (Cook et al. 2008). For the dry years (Figs. $7 \mathrm{~b}$ and c), the 500-hPa patterns are nearly mirror images of the wet years. There are anomalous high 500-hPa heights with associated anomalous anticyclonic (clockwise) winds in nearly the same location as the low and cyclonic winds from the wet years (Fig. 7b). In contrast, the $850-\mathrm{hPa}$ heights and winds show an asymmetrical pattern. The $850-\mathrm{hPa}$ heights for the dry years have a small high over the SEPPR, one that is much smaller in size and magnitude than the low seen in the wet years (Fig. 7d). Wind anomalies at the 850 -hPa level are weak with no predominant pattern (Fig. 7d).

There are two regions of anomalous SSTs during the wet years (Fig. 8a). The first is a sandwich pattern (low or high values with the opposite immediately north and south) in the North Atlantic Ocean, and the second is a pattern resembling the Pacific decadal oscillation (PDO) in the northern Pacific Ocean (Fig. 8a), both similar to the one seen in Fig. 5a. For the dry years (Fig. 8b), there is no sandwich pattern in the Atlantic Ocean SSTs (as seen in Fig. 8a). Most prominently, there are negative SST anomalies in the equatorial Pacific reminiscent of an ENSO pattern (La Niña, since they are negative anomalies) for these dry years, indicating a connection to ENSO cycles (Fig. 8b).

There are anomalously high PDSI values (positive PDSI values indicate wet conditions) in the SEPPR and south and southwest of the SEPPR (Fig. 8c). Note that some of the region with anomalously high PDSI values is coincident with the highest values of PDSI correlation seen in Fig. 5c. During the dry years, the PDSI values over the SEPPR are a mirror image with them being negative (Fig. 8d). Nearly all of the northern part of the United States (above 

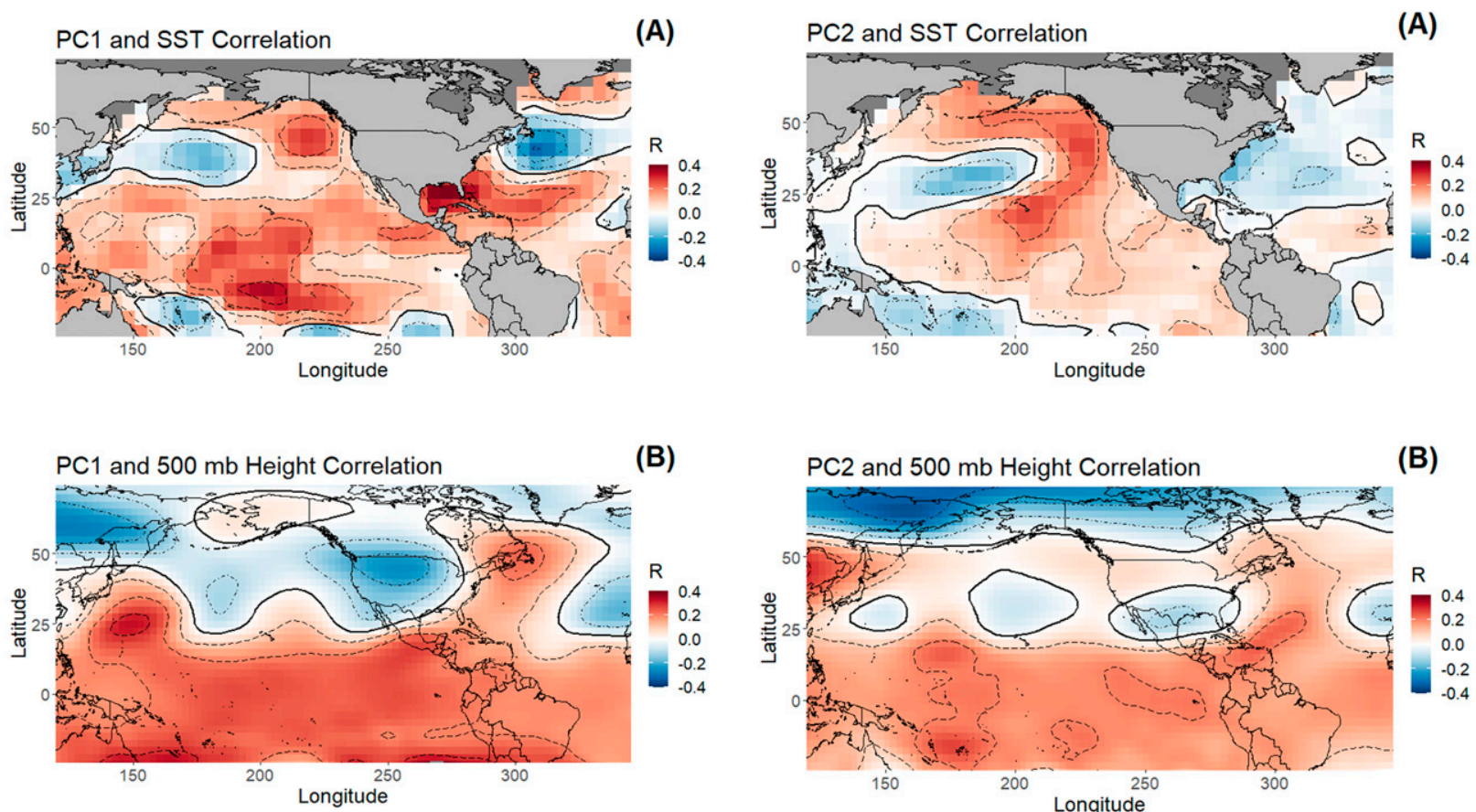

(B)
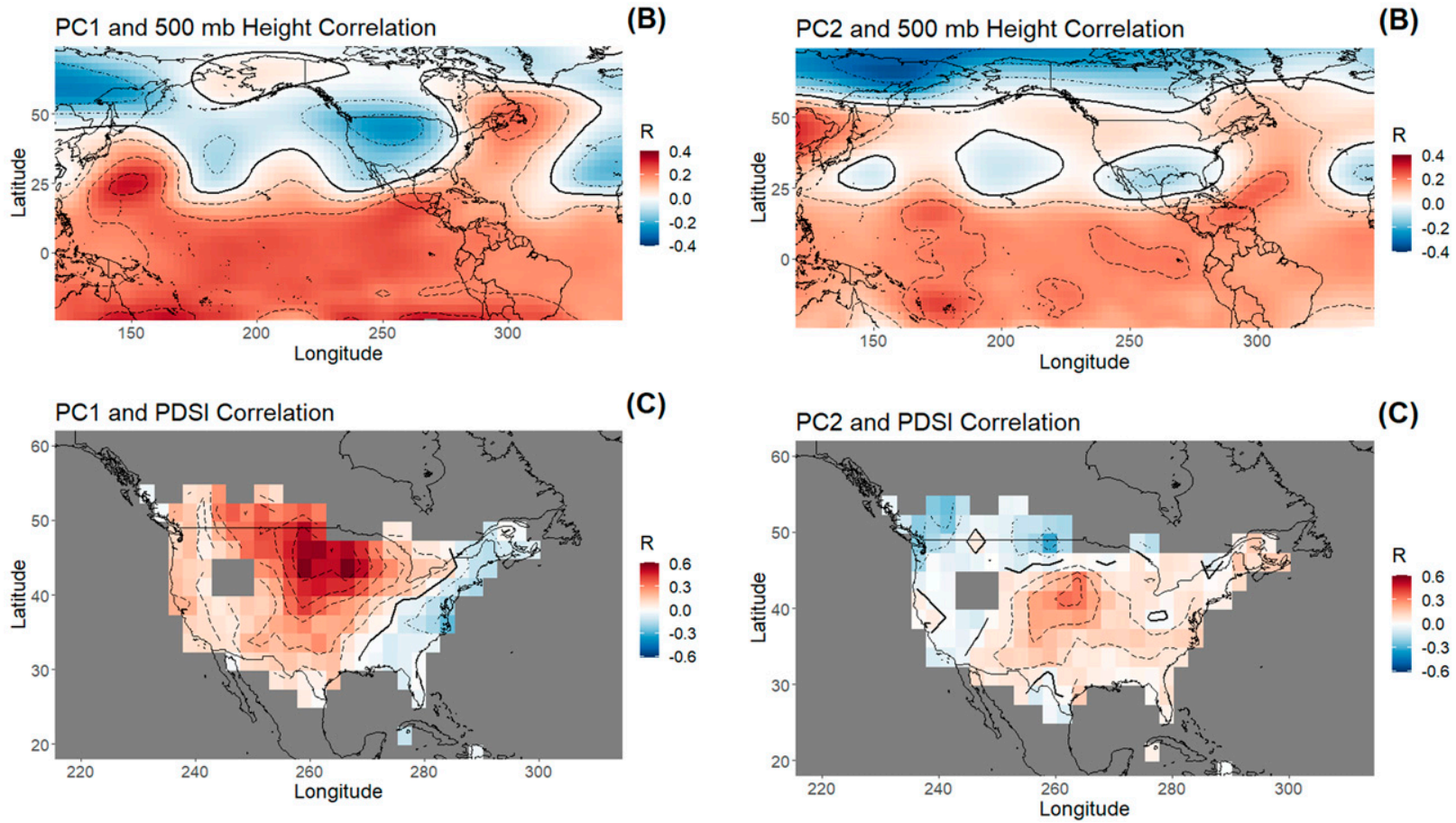

FIG. 5. PC1 correlation with JJAS (a) SST anomalies, (b) 500$\mathrm{hPa}$ heights, and (c) PDSI. Positive contours are dashed lines, negative contours are dot-dashed lines, and the 0 contour is a solid line. The contour interval is 0.1 .

$40^{\circ} \mathrm{N}$ ) has negative PDSI anomalies during the dry years (Fig. 8d).

\section{Summary and discussion}

Summer precipitation in the SEPPR is one of two major water sources for wetland and pond habitat for waterfowl and other species. Summer precipitation variability, therefore, contributes to habitat availability in the SEPPR. With our analysis of the summer precipitation variability in the SEPPR, this study has identified large-scale teleconnections via SST, 500-hPa heights, and PDSI, and potential driving mechanisms via 500- and 850-hPa heights and winds and PDSI. Our results show a coupling between land (PDSI), atmosphere (500- and 850-hPa heights and winds), and oceans (SST) that potentially

FIG. 6. As in Fig. 5, but for PC2.

drives climate variability in the SEPPR. Couplings such as these provide predictability. This coupling is exploited in Abel et al. (2020), which uses canonical correlation analysis to predict regional pond counts from some of these large-scale variables.

The first PC from our PCA on summer precipitation in the SEPPR showed homogeneity in spatial loadings; they are all the same sign and similar in magnitude. This means one or more common physical mechanism(s) is causing the variability. One possibility is storm systems associated with largescale patterns (such as the 500-hPa lows seen in our analysis) that bring precipitation to the entire region. These large-scale patterns could bring thunderstorms or squall lines to the entire region over the course of the summer. Conversely, PC2 showed a north-south dipole- the north SEPPR has positive spatial loadings, and the south SEPPR has negative loadings. This might be explained by a storm track that shifts precipitation from the northern part of the region to the southern part 

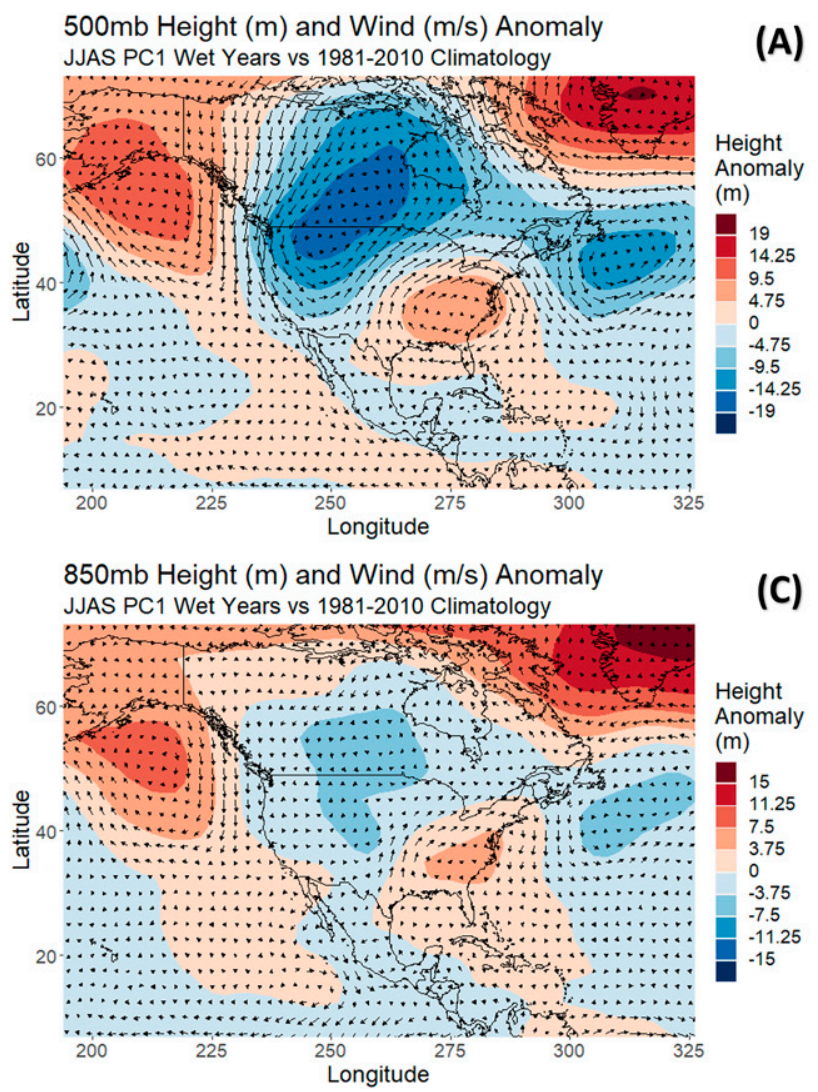
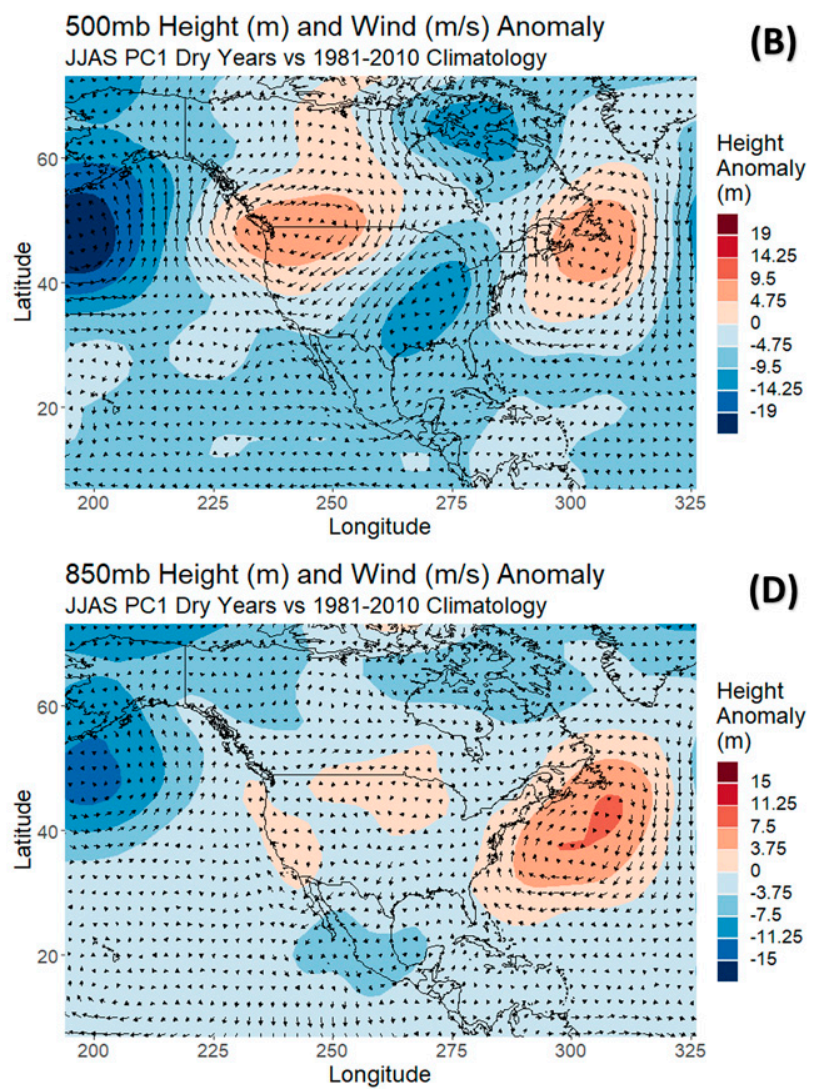

FIG. 7. Summer composites of the (left) wet and (right) dry years of PC1 for (a),(b) 500- and (c),(d) 850-hPa heights and wind anomalies.

of the region or from the southern part to the northern part, leading to inhomogeneous variability. The predominant jet stream location during the summer months influences the storm track, which in turn produces more precipitation in the northern part and less precipitation in the southern part of the region. Liu et al. (1998) show that the location of the jet stream can be impacted by SSTs. Further, precipitation in the Great Plains (southern and northern) is linked to the location of the jet stream, which is tied to an anomalously negative North Atlantic Oscillation (NAO; Pu et al. 2016). Therefore, it is plausible that the precipitation variability is all tied together via SSTs and its impact on the jet stream. Another possibility is moisture and precipitation brought to the southern part of the SEPPR by the GPLLJ, but not to the north. $\mathrm{Pu}$ et al. (2016) found that moisture is moved northward from the southern Great Plains by an intensified GPLLJ; this would also potentially explain the dipole seen in the PC2 spatial loadings. If precipitation (and its associated variability) is brought only to the southern SEPPR, this would cause the inhomogeneous variability signals in the northern and southern SEPPR seen in PC2.

Commonly, the trend of the data (in this case the climate change trend) is captured in the first (or sometimes second) PC. We notice a statistically significant trend in PC1 and no trend in PC2. The PC1 climate trend may be one explanation of the homogeneity seen in PC1 loadings but is not large enough in magnitude to explain it entirely. This positive trend agrees with the findings of Ballard et al. (2014) that summer precipitation in the region has been increasing since around 1990.

Our analysis finds large-scale teleconnections to Pacific and Atlantic SSTs with signatures resembling climate indices such as PDO and ENSO. Shabbar et al. (2011) found connections between precipitation and Pacific SSTs including signatures resembling ENSO, but these results are for the Canadian PPR. Other studies have found that precipitation variability in the Great Plains has teleconnections to Pacific Ocean SSTs (Ting and Wang 1997; Ruiz-Barradas and Nigam 2005; Hu and Huang 2009; Capotondi and Alexander 2010), although they do not focus on the PPR. However, it should be noted that the Great Plains studies do not fully agree on where in the Pacific Ocean the teleconnections exist. One only noted connections to equatorial/tropical SSTs (Capotondi and Alexander 2010) while others noted connections to both equatorial/tropical and northern SSTs (Ting and Wang 1997; Ruiz-Barradas and Nigam 2005; Hu and Huang 2009). There have been studies that have not found a connection between Great Plains wetness and SSTs (Seager and Hoerling 2014; Flanagan et al. 2019), but these have been focused on a subset of years. One of the noted studies found connections to North 


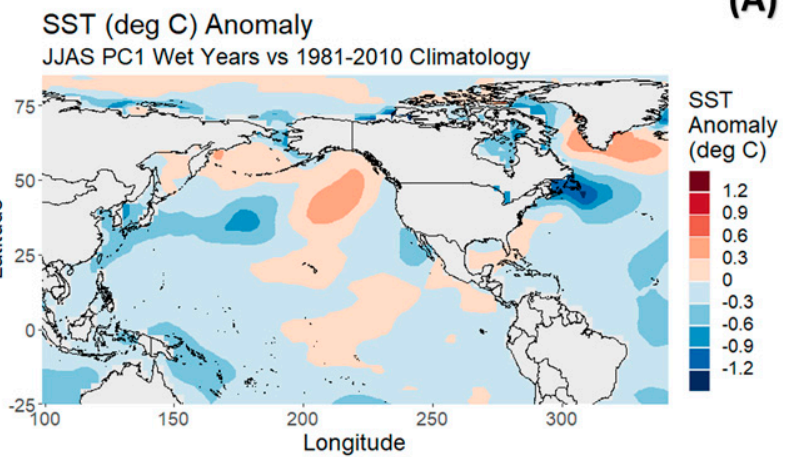

\section{(A)}
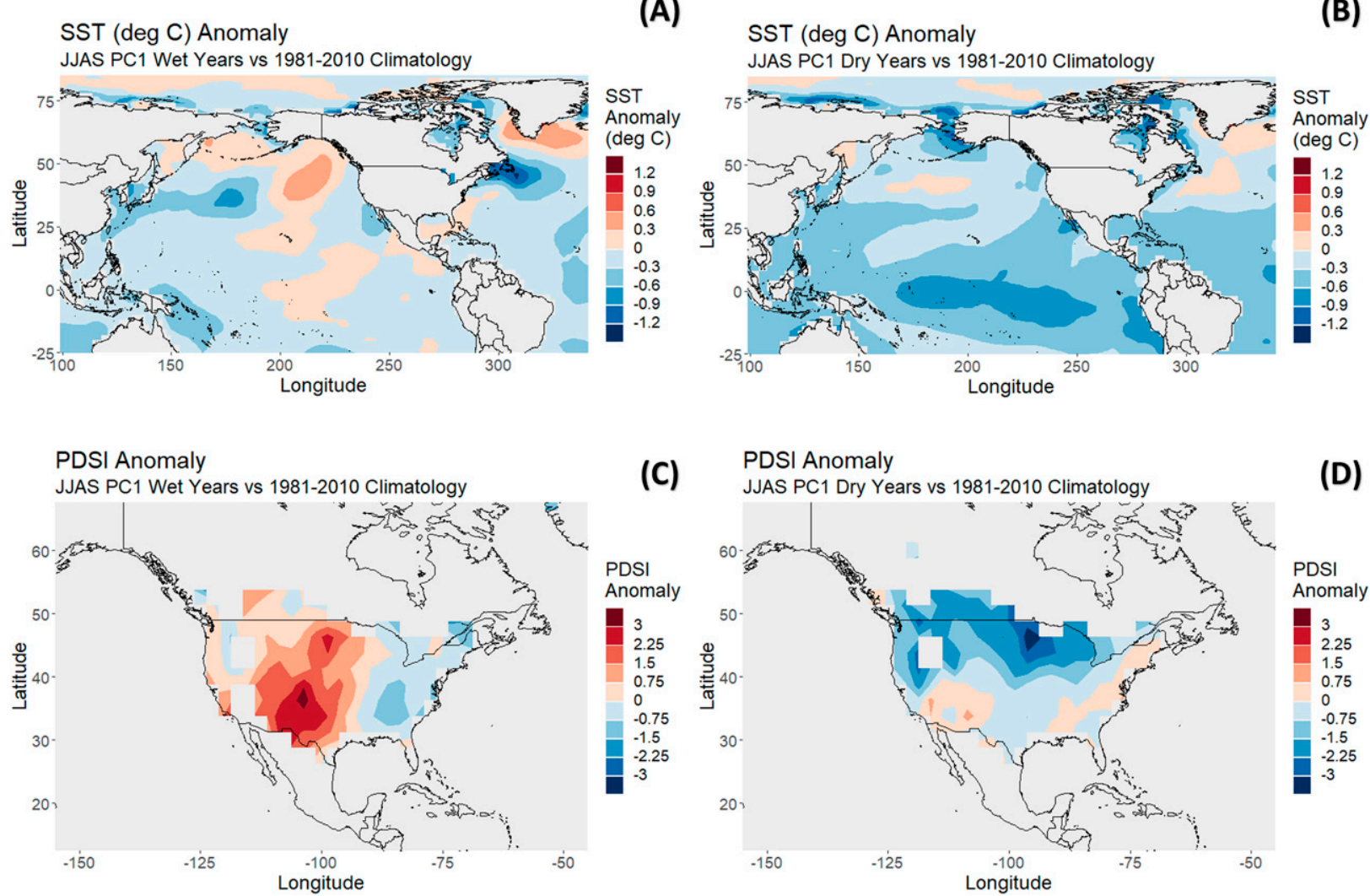

FIG. 8. As in Fig. 7, but for (a),(b) SST and (c),(d) PDSI anomalies.

Atlantic Ocean SSTs (Ruiz-Barradas and Nigam 2005), whereas other studies have found connections to tropical Atlantic SSTs (Schubert2004; Kushnir et al. 2010). With that context, we believe the presence of the Pacific SST correlations in both PCs indicate a possible connection to the PDO, with the PC2 pattern being very reminiscent of that climate index. The small correlation of PC1 to equatorial Pacific SST resembles the pattern of ENSO. Connections to both these indices were noted by $\mathrm{Hu}$ and Huang (2009), and Ting and Wang (1997) noted the connection to ENSO. We provide further evidence of connections to ENSO and PDO by performing a wavelet analysis (Torrence and Compo 1998) on PC1, the summer-averaged Niño-4 index, and the summer-averaged PDO index. This brief analysis is in the online supplemental material in the "Wavelet analysis" section and Figs. S8 and S9.

We also noticed large-scale teleconnections to northwestern U.S. 500-hPa heights and PDSI in the SEPPR and central United States. The 500-hPa-PC1 correlations displayed over the northwest United States could bring moisture from the Pacific Ocean into the SEPPR and enhance storm development; this negative correlation indicates a connection to anomalous low 500-hPa heights. The general north-south pattern seen in the correlation between PC2 and 500-hPa heights is indicative of the common north-south distribution of heights in the atmosphere. The correlations between PC1 and
PDSI (from 0.4 to 0.6 ) indicate a connection between precipitation variability and PDSI in the SEPPR. This is not unexpected because precipitation is used in the calculation of PDSI. PC2 and PDSI correlate over the central United States (from 0.2 to 0.4 ), indicating a potential teleconnection. The correlations of both PCs with PDSI may also indicate a connection to soil moisture since it is also a part of calculating PDSI.

We posit that mechanisms driving the variability are anomalous $500-\mathrm{hPa}$ heights and winds over the northwest United States and Pacific and Atlantic SSTs. Anomalous 850-hPa heights in the north-central United States also possibly impact variability, and $850-\mathrm{hPa}$ winds during wet years display a pattern like the GPLLJ. La Niña potentially plays a role in this variability, as seen in the dry years' SST composite map-La Niña years may experience decreased precipitation.

The posited mechanisms that cause variability can be concluded based on our results from our wet and dry year analysis. Large-scale lows and their associated cyclonic winds are a major ingredient in thunderstorm generation-this is a likely mechanism of variability based on the 500- and 850 -hPa composites. The associated wind patterns indicate two possible sources for moisture in the region: the Pacific Ocean and the Gulf of Mexico (via the GPLLJ). These two potential mechanisms for bringing moisture to the region would provide another major ingredient in thunderstorm generation. The 
GPLLJ wind pattern could also indicate that large systems such as tropical storms persist and move as far north as the SEPPR. Conversely, large-scale high pressure systems and anticyclonic winds would inhibit thunderstorm generation in the region. The positive PDSI values that are observed in and to the southwest of the SEPPR could be indicative of a storm track from the southwest that produces thunderstorms over the regions of positive PDSI values. The positive values could also indicate a third possible moisture source-landbecause soil moisture is incorporated in the calculation of PDSI. Negative PDSI values indicate conditions that would cut off this storm track by depriving potential storms of moisture.

We hypothesize that the teleconnections and posited mechanisms are physically linked to influence SEPPR summer precipitation variability. The teleconnections discovered by our analysis physically modulate the GPLLJ to ultimately increase/decrease precipitation in the SEPPR. Reasoning for our hypothesis comes from findings of a link between the summer GPLLJ and PDO/ENSO (Malloy and Kirtman 2020; Krishnamurthy et al. 2015; Yu et al. 2017; Song et al. 2005), and work linking large-scale, upper-level heights over the Pacific and Atlantic Oceans (Weaver and Nigam 2008). The GPLLJ has been found to be stronger and occur more frequently during La Niña (Malloy and Kirtman 2020; Krishnamurthy et al. 2015; Song et al. 2005) and cool phase of PDO (Song et al. 2005). Malloy and Kirtman (2020) also found that opposite SSTs in the tropical Pacific and North Atlantic result in low-level circulation patterns that favor a stronger GPLLJ. Ultimately, they conclude that a strengthened Caribbean LLJ, negative Pacific-North American (PNA) teleconnection, El Niño, and a negative Atlantic multidecadal oscillation are potential predictors of a strengthened GPLLJ highlighting the first two as the strongest candidates for improving monthly forecasts (Malloy and Kirtman 2020). Weaver and Nigam (2008) specifically identified the strengthening and expansion of the GPLLJ core and a meridional shift of the GPLLJ as being linked to large-scale height patterns and ENSO variability. Our results and these previous studies imply that SSTs are modulating the GPLLJ, and if so, would ultimately affect precipitation. One possible mechanism involved is the strengthening and expansion of the GPLLJ core causing more precipitation, as found in Weaver and Nigam (2008), along with the strengthening of the GPLLJ due to increased soil moisture (Li et al. 2016, 2017). The insights from our study and previous results lead us to conclude that the SST teleconnections are physically strengthening or weakening the GPLLJ by affecting its core strength. The GPLLJ is further strengthened by the underlying soil moisture content. Taken together, these processes modulate the precipitation in the SEPPR.

A further importance of this work relates to projected climate changes in the region, including increased variability. The region will have a higher occurrence of both droughts and heat waves (Conant et al. 2018) superimposed over increasing annual average temperature and precipitation (Kunkel et al. 2013). In the SEPPR, rainfall in summer will decrease but will increase in other seasons (Ballard et al.
2014; Kunkel et al. 2013). This will alter the balance of precipitation and evaporation (Ballard et al. 2014). Temperature, although projected to increase in all seasons, will have the greatest increase in winter and the smallest increase in spring (Ballard et al. 2014).

Our findings contribute to understanding the climate variability in the SEPPR. This study is novel in the literature on SEPPR precipitation, which lacks investigation into the driving mechanisms of the precipitation variability. Our results reinforce using PDSI as a predictor as was done in two predictive modeling studies. Huang et al. (2011) integrated PDSI into a physical model and were able to skillfully simulate surface area of ponds. Sorenson et al. (1998) observed that PDSI correlated well with both pond and duck counts in May and used it to make predictions on pond and duck counts for future scenarios. Just as our results imply, Ballard et al. (2014) noticed a weak relationship between pond and duck numbers and La Niña events. Our findings corroborate these previous studies but also provide the potential driving mechanisms and teleconnections. Future work could evolve these findings into predictive studies as in Abel et al. 2020. These findings thus can ultimately inform management actions to maintain and restore wildlife habitat and the resources used for those actions in the PPR. Our results imply that these large-scale teleconnections and potential mechanisms have predictive utility for waterfowl habitat.

Acknowledgments. The authors gratefully acknowledge funding for this research from National Science Foundation (NSF) Grant 1243270 "Linking near-term future changes in weather and hydroclimate in western North America to adaptation for ecosystem and water management." Author Andrea J. Ray was funded by the NOAA/Physical Sciences Laboratory. Composite images were provided by the NOAA/Physical Sciences Laboratory (https://psl.noaa.gov/ cgi-bin/data/getpage.pl). We thank Bruce Millett for the original PPR shapefile and Angela Boag for PPR shapefile modification. We thank three anonymous reviewers whose comments helped to improve this paper.

Data availability statement. The data that support the findings of this study are openly available at the following URL/ DOIs: NOAA/NCEI nClimDiv (https://doi.org/10.7289/ V5M32STR), IRI Data Library (https://iridl.ldeo.columbia. edu/), NOAA/PSL Climate Data Repository (https://psl.noaa. gov/repository/a/psdgrids), and NOAA/PSL Anomaly Composites (https://psl.noaa.gov/cgi-bin/data/getpage.pl).

\section{REFERENCES}

Abel, B., B. Rajagopalan, and A. Ray, 2020: A predictive model for seasonal pond counts in the United States Prairie Pothole Region using large-scale climate connections. Environ. Res. Lett., 15, 044019, https://doi.org/10.1088/1748-9326/ab7465.

Anteau, M., M. Wiltermuth, M. Burg, and A. Pearse, 2016: Prerequisites for understanding climate-change impacts on northern prairie wetlands. Wetlands, 36, 299-307, https://doi.org/10. 1007/s13157-016-0811-2. 
Balas, C., N. Euliss, and D. Mushet, 2012: Influence of conservation programs on amphibians using seasonal wetlands in the Prairie Pothole Region. Wetlands, 32, 333-345, https://doi.org/ 10.1007/s13157-012-0269-9.

Ballard, T., and Coauthors, 2014: Hydroclimate variability and change in the Prairie Pothole Region, the "Duck Factory" of North America. Earth Interact., 18, https://doi.org/10.1175/EID-14-0004.1.

Batt, B., M. Anderson, C. Anderson, and F. Caswell, 1989: The use of prairie potholes by North American ducks. Northern Prairie Wetlands, A. van der Valk, Ed., Iowa State University Press, 204-227.

Brunnschweiler, D., 1952: The geographic distribution of air masses in North America. Vie Vierteljahrsschr. Naturforsch. Ges. Zuerich, 97, 42-49.

Bryson, R., and F. Hare, 1974: Climates of North America. World Survey of Climatology, H. Landsberg, Ed., Vol. 11, Elsevier, $1-47$.

Capotondi, A., and M. Alexander, 2010: Relationship between precipitation in the Great Plains of the United States and global SSTs: Insights from the IPCC AR4 models. J. Climate, 23, 2941-2958, https://doi.org/10.1175/2009JCLI3291.1.

Cattell, R., 1966: The Scree test for the number of factors. Multivar. Behav. Res., 1, 245-276, https://doi.org/10.1207/ s15327906mbr0102_10.

Conant, R., and Coauthors, 2018: Northern Great Plains. Impacts, Risks, and Adaptation in the United States: Fourth National Climate Assessment, Vol. II, D. Reidmiller et al., Eds., U.S. Global Change Research Program, 941-986, https://doi.org/ 10.7930/NCA4.2018.CH22.

Cook, K., E. Vizy, Z. Launer, and C. Patricola, 2008: Springtime intensification of the Great Plains low-level jet and Midwest precipitation in GCM simulations of the twentyfirst century. J. Climate, 21, 6321-6340, https://doi.org/ 10.1175/2008JCLI2355.1.

Cox, D., and A. Stuart, 1955: Some quick sign tests for trend in location and dispersion. Biometrika, 42, 80-95, https://doi.org/ 10.1093/biomet/42.1-2.80.

Dahl, T., 2014: Status and trends of prairie wetlands in the United States 1997 to 2009. U.S. Department of the Interior Fish and Wildlife Service Ecological Services Doc., 80 pp., https:// www.fws.gov/wetlands/Documents/Status-and-Trends-ofPrairie-Wetlands-in-the-United-States-1997-to-2009.pdf.

Dai, A., K. E. Trenberth, and T. Qian, 2004: A global dataset of Palmer drought severity index for 1870-2002: Relationship with soil moisture and effects of surface warming. J. Hydrometeor., 5, 1117-1130, https://doi.org/10.1175/JHM-386.1.

DeAngelis, A., F. Dominguez, Y. Fan, A. Robock, M. Kustu, and D. Robinson, 2010: Evidence of enhanced precipitation due to irrigation over the Great Plains of the United States. J. Geophys. Res., 115, D15115, https://doi.org/10. 1029/2010JD013892.

Diffenbaugh, N., 2009: Influence of modern land cover on the climate of the United States. Climate Dyn., 33, 945-958, https:// doi.org/10.1007/s00382-009-0566-z.

Dyke, S., S. Johnson, and P. Isakson, 2015: North Dakota State wildlife action plan. North Dakota Game and Fish Department Doc., 468 pp., https://gf.nd.gov/sites/default/ files/publications/swap-2015_0.pdf.

Flanagan, P., J. Basara, J. Furtado, and X. Xiao, 2018: Primary atmospheric drivers of pluvial years in the United States Great Plains. J. Hydrometeor., 19, 643-658, https://doi.org/10. 1175/JHM-D-17-0148.1.
,,--- , E. Martin, and X. Xiao, 2019: Role of sea surface temperatures in forcing circulation anomalies driving U.S. Great Plains pluvial years. J. Climate, 32, 7081-7100, https://doi.org/10.1175/JCLI-D-18-0726.1.

Gleason, R., and A. Tangen, 2008: Floodwater storage. Ecosystem services derived from wetland conservation practices in the United States Prairie Pothole Region with an emphasis on the U.S. Department of Agriculture Conservation Reserve and Wetlands Reserve Programs, R. Gleason, M. Laubhan, and N. Euliss Jr., Eds., U.S. Geological Survey Professional Paper 1745, 31-37.

— N. N. Euliss Jr., B. Tangen, M. Laubhan, and B. Browne, 2011: USDA conservation program and practice effects on wetland ecosystem services in the Prairie Pothole Region. Ecol. Appl., 21, S65-S81, https://doi.org/10.1890/09-0216.1.

Hayashi, M., G. Kamp, and D. Rosenberry, 2016: Hydrology of prairie wetlands: Understanding the integrated surface-water and groundwater processes. Wetlands, 36, 237-254, https:// doi.org/10.1007/s13157-016-0797-9.

Howerter, D., M. Anderson, J. Devries, B. Joynt, L. Armstrong, R. Emery, and T. Arnold, 2014: Variation in mallard vital rates in Canadian Aspen Parklands: The prairie habitat joint venture assessment. Wildlife Monogr., Vol. 188, Wildlife Society, 1-37, https://doi.org/10.1002/wmon.1012.

$\mathrm{Hu}, \mathrm{Z}$., and B. Huang, 2009: Interferential impact of ENSO and PDO on dry and wet conditions in the U.S. Great Plains. J. Climate, 22, 6047-6065, https://doi.org/10.1175/2009JCLI2798.1.

Huang, B., and Coauthors, 2017: NOAA Extended Reconstructed Sea Surface Temperature (ERSST), version 5. National Centers for Environmental Information, accessed 12 January 2021, https://doi.org/10.7289/V5T72FNM.

Huang, S., D. Dahal, C. Young, G. Chander, and S. Liu, 2011: Integration of Palmer drought severity index and remote sensing data to simulate wetland water surface from 1910 to 2009 in Cottonwood Lake area, North Dakota. Remote Sens. Environ., 115, 3377-3389, https://doi.org/10.1016/j.rse.2011.08. 002.

Johnson, W. C., and K. Poiani, 2016: Climate change effects on Prairie Pothole wetlands: Findings from a twenty-five year numerical modeling project. Wetlands, 36, 273-285, https:// doi.org/10.1007/s13157-016-0790-3.

_ S. Boettcher, K. Poiani, and G. Guntenspergen, 2004: Influences of weather extremes on the hydrology of glaciated prairie wetlands. Wetlands, 24, 385-398, https://doi.org/10.1672/ 0277-5212(2004)024[0385:IOWEOT]2.0.CO;2.

—, B. V. Millett, T. Gilmanov, R. A. Voldseth, G. R. Guntenspergen, and D. E. Naugle, 2005: Vulnerability of northern prairie wetlands to climate change. BioScience, 55, 863-872, https://doi.org/10.1641/0006-3568(2005)055[0863:VONPWT]2. $0 . \mathrm{CO} ; 2$.

Johnson, W., and Coauthors, 2010: Prairie wetland complexes as landscape functional units in a changing climate. BioScience, 60, 128-140, https://doi.org/10.1525/bio.2010.60.2.7.

Jolliffe, I., 2002: Principal Component Analysis. Springer, 518 pp., https://doi.org/10.1007/b98835.

- and J. Cadima, 2016: Principal component analysis: A review and recent developments. Philos. Trans. Roy. Soc., A374, 20150202, https://doi.org/10.1098/rsta.2015.0202.

Kalnay, E., and Coauthors, 1996: The NCEP/NCAR 40-Year Reanalysis Project. Bull. Amer. Meteor. Soc., 77, 437-472, https://doi.org/10.1175/1520-0477(1996)077<0437:TNYRP $>2$. $0 . \mathrm{CO} ; 2$. 
Kantrud, H., G. Krapu, and G. Swanson, 1989: Prairie basin wetlands of the Dakotas: A community profile. U.S. Fish and Wildlife Service Biological Rep. 85(7.28), 111 pp., https:// pubs.er.usgs.gov/publication/2000127.

Kaplan, A., M. Cane, Y. Kushnir, A. Clement, M. Blumenthal, and B. Rajagopalan, 1998: Analyses of global sea surface temperature 1856-1991. J. Geophys. Res., 103, 18567-18589, https://doi.org/10.1029/97JC01736.

Krishnamurthy, L., G. Vecchi, R. Msadek, A. Wittenberg, T. Delworth, and F. Zeng, 2015: The seasonality of the Great Plains low-level jet and ENSO relationship. J. Climate, 28, 4525-4544, https://doi.org/10.1175/JCLI-D-14-00590.1.

Kunkel, K., and Coauthors, 2013: Climate of the U.S. Great Plains. Regional climate trends and scenarios for the U.S. National Climate Assessment, Part 4, NOAA Tech. Rep. NESDIS 142-4, 91 pp., https://scenarios.globalchange.gov/ sites/default/files/NOAA_NESDIS_Tech_Report_142-4Climate_of_the_U.S.\%20Great_Plains_0.pdf.

Kushnir, Y., R. Seager, M. Ting, N. Naik, and J. Nakamura, 2010: Mechanisms of tropical Atlantic SST influence on North American precipitation variability. J. Climate, 23, 5610-5628, https://doi.org/10.1175/2010JCLI3172.1.

LaBaugh, J., D. Mushet, D. Rosenberry, N. Euliss, M. Goldhaber, C. Mills, and R. Nelson, 2016: Changes in pond water levels and surface extent due to climate variability alter solute sources to closed-basin prairie-pothole wetland ponds, 1979 to 2012. Wetlands, 36, 343-355, https://doi.org/10.1007/s13157016-0808-x.

- D. Rosenberry, D. Mushet, B. Neff, R. Nelson, and N. Euliss, 2018: Long-term changes in pond permanence, size, and salinity in Prairie Pothole Region wetlands: The role of groundwater-pond interaction. J. Hydrol. Reg. Stud., 17, 1-23, https://doi.org/10.1016/j.ejrh.2018.03.003.

Larson, D., 1995: Effects of climate on numbers of northern prairie wetlands. Climatic Change, 30, 169-180, https://doi.org/10. 1007/BF01091840.

Li, L., R. Schmitt, C. Ummenhofer, and K. Karnauskas, 2016: Implications of North Atlantic Sea surface salinity for summer precipitation over the U.S. Midwest: Mechanisms and predictive value. J. Climate, 29, 3143-3159, https://oi.org/10. 1175/JCLI-D-15-0520.1.

,-- , and - 2017: The role of the subtropical North Atlantic water cycle in recent us extreme precipitation events. Climate Dyn., 50, 1291-1305, https://doi.org/10.1007/s00382017-3685-y.

Liu, A. Z., M. Ting, and H. Wang, 1998: Maintenance of circulation anomalies during the 1988 drought and 1993 floods over the United States. J. Atmos. Sci., 55, 2810-2832, https:// doi.org/10.1175/1520-0469(1998)055<2810:MOCADT $>2$. $0 . \mathrm{CO} ; 2$.

Liu, G., and F. Schwartz, 2012: Climate-driven variability in lake and wetland distribution across the Prairie Pothole Region: From modern observations to long-term reconstructions with space-for-time substitution. Water Resour. Res., 48, W08526, https://doi.org/10.1029/2011WR011539.

Lobell, D., G. Bala, A. Mirin, T. Phillips, R. Maxwell, and D. Rotman, 2009: Regional differences in the influence of irrigation on climate. J. Climate, 22, 2248-2255, https://doi.org/10.1175/ 2008JCLI2703.1.

Malloy, K., and B. Kirtman, 2020: Predictability of midsummer Great Plains low-level jet and associated precipitation. Wea. Forecasting, 35, 215-235, https://doi.org/10.1175/WAF-D-190103.1.
McCauley, L., M. Anteau, M. Burg, and M. Wiltermuth, 2015: Land use and wetland drainage affect water levels and dynamics of remaining wetlands. Ecosphere, 6 (4), 1-22, https://doi.org/10.1890/ES14-00514.1.

McKenna, O., D. Mushet, D. Rosenberry, and J. LaBaugh, 2017: Evidence for a climate-induced ecohydrological state shift in wetland ecosystems of the southern Prairie Pothole Region. Climatic Change, 145, 273-287, https://doi.org/10.1007/s10584017-2097-7.

Millett, B., W. Johnson, and G. Guntenspergen, 2009: Climate trends of the North American prairie pothole region 1906-2000. Climatic Change, 93, 243-267, https://doi.org/10. 1007/s10584-008-9543-5.

Mushet, D., 2016: Midcontinent prairie-pothole wetlands and climate change: An introduction to the supplemental issue. Wetlands, 36, 223-228, https://doi.org/10.1007/s13157-016-0852-6.

Niemuth, N., B. Wangler, and R. Reynolds, 2010: Spatial and temporal variation in wet area of wetlands in the Prairie Pothole Region of North Dakota and South Dakota. Wetlands, 30, 1053-1064, https://doi.org/10.1007/s13157-010-0111-1.

Pomeroy, J., D. Gray, K. Shook, B. Toth, R. Essery, A. Pietroniro, and N. Hedstrom, 1998: An evaluation of snow accumulation and ablation processes for land surface modelling. Hydrol. Processes, 12, 2339-2367, https://doi.org/10.1002/ (SICI)1099-1085(199812)12:15<2339::AID-HYP800>3.0. CO;2-L.

Pu, B., R. Fu, R. Dickinson, and D. Fernando, 2016: Why do summer droughts in the southern Great Plains occur in some La Niña years but not others? J. Geophys. Res. Atmos., 121, 1120-1137, https://doi.org/10.1002/2015JD023508.

Quiring, S. M., T. W. Ford, J. K. Wang, A. Khong, E. Harris, T. Lindgren, D. W. Goldberg, and Z. Li, 2016: The North American Soil Moisture Database: Development and applications. Bull. Amer. Meteor. Soc., 97, 1441-1459, https://doi.org/ 10.1175/BAMS-D-13-00263.1.

Reynolds, R., and T. Smith, 1994: Improved global sea surface temperature analyses using optimum interpolation J. Climate, 7, 929-948, https://doi.org/10.1175/1520-0442(1994)007<0929: IGSSTA $>2.0 . \mathrm{CO} ; 2$.

Rosenberry, D., 2003: Climate of the cottonwood lake area. Hydrological, chemical, and biological characteristics of a prairie pothole wetland complex under highly variable climate conditions-The Cottonwood Lake Area, east-central North Dakota, T. Winter, Ed., U.S. Geological Survey Professional Paper 1675, 25-34, https://doi.org/10.3133/pp1675.

Ruiz-Barradas, A., and S. Nigam, 2005: Warm season rainfall variability over the U.S. Great Plains in observations, NCEP and ERA-40 reanalyses, and NCAR and NASA atmospheric model simulations. J. Climate, 18, 1808-1830, https://doi.org/ 10.1175/JCLI3343.1.

Sacks, W., B. Cook, N. Buenning, S. Levis, and J. Helkowski, 2009: Effects of global irrigation on the near-surface climate. Climate Dyn., 33, 159-175, https://doi.org/10.1007/s00382-0080445-z.

Schubert, S., 2004: On the cause of the 1930s dust bowl. Science, 303, 1855-1859, https://doi.org/10.1126/science.1095048.

Seager, R., and M. Hoerling, 2014: Atmosphere and ocean origins of North American droughts. J. Climate, 27, 4581-4606, https://doi.org/10.1175/JCLI-D-13-00329.1.

Shabbar, A., B. Bonsal, and K. Szeto, 2011: Atmospheric and oceanic variability associated with growing season droughts and pluvials on the Canadian prairies. Atmos.-Ocean, 49, 339355, https://doi.org/10.1080/07055900.2011.564908. 
Sleeter, B., T. Loveland, G. Domke, N. Herold, J. Wickham, and N. Wood, 2018: Land cover and land-use change. Impacts, Risks, and Adaptation in the United States: Fourth National Climate Assessment, Vol. II, D. R. Reidmiller et al., Eds., U.S. Global Change Research Program, 202-231, https://doi. org/10.7930/NCA4.2018.CH5.

Smith, A., J. Stoudt, and J. Gallop, 1964: Prairie pothole wetlands and marshes. Waterfowl Tomorrow, J. Linduska, Ed., U.S. Government Printing Office, 39-50.

Song, J., K. Liao, R. Coulter, and B. Lesht, 2005: Climatology of the low-level jet at the Southern Great Plains atmospheric boundary layer experiments site. J. Appl. Meteor., 44, 15931606, https://doi.org/10.1175/JAM2294.1.

Sorenson, L., R. Goldberg, T. Root, and M. Anderson, 1998: Potential effects of global warming on waterfowl populations breeding in the northern Great Plains. Climatic Change, 40, 343-369, https://doi.org/10.1023/A:1005441608819.

Steen, V., S. Skagen, and B. Noon, 2014: Vulnerability of breeding waterbirds to climate change in the Prairie Pothole Region, USA. PLOS ONE, 9, e96747, https://doi.org/10.1371/journal. pone.0096747.

Ting, M., and H. Wang, 1997: Summertime U.S. precipitation variability and its relation to Pacific sea surface temperature. J. Climate, 10, 1853-1873, https://doi.org/10.1175/1520-0442 (1997) $010<1853:$ SUSPVA $>2.0$. CO;2.

Torrence, C., and G. Compo, 1998: A practical guide to wavelet analysis. Bull. Amer. Meteor. Soc, 79, 61-78, https://doi.org/ 10.1175/1520-0477(1998)079<0061:APGTWA > 2.0.CO;2.

U.S. Fish and Wildlife Service, 2015: Kulm wetland management district habitat management plan. U.S. Department of the Interior Fish and Wildlife Service, accessed 21 February 2020, https://ecos.fws.gov/ServCat/DownloadFile/50591. van der Valk, A., 2005: Water-level fluctuations in North American prairie wetlands. Hydrobiologia, 539, 171-199, https://doi. org/10.1007/s10750-004-4866-3.

Vecchia, A., 2008: Climate simulation and flood risk analysis for 2008-40 for Devils Lake, North Dakota. U.S. Geological Survey Scientific Investigations Rep. 2008-5011, 29 pp., https:// doi.org/10.3133/sir20085011.

von Storch, H., 1999: Spatial patterns: EOFs and CCA. Analysis of Climate Variability, H. von Storch and A. Navarra, Eds., Springer, 231-263.

Vose, R. S., and Coauthors, 2014: NOAA's Gridded Climate Divisional Dataset (CLIMDIV) [prcp]. NOAA National Climatic Data Center, accessed 26 January 2018, https://doi.org/ 10.7289/V5M32STR.

Weaver, S., and S. Nigam, 2008: Variability of the Great Plains low-level jet: Large-scale circulation context and hydroclimate impacts. J. Climate, 21, 1532-1551, https://doi.org/10. 1175/2007JCLI1586.1.

White, C., and Coauthors, 2017: Potential applications of subseasonal-to-seasonal (S2S) predictions. Meteor. Appl., 24, 315325, https://doi.org/10.1002/met.1654.

Winter, T., 2000: The vulnerability of wetlands to climate change: A hydrologic landscape perspective. J. Amer. Water Resour. Assoc., 36, 305-311, https://doi.org/10.1111/j.1752-1688.2000. tb04269.x.

Yocum, H., and A. Ray, 2019: Climate information to support wildlife management in the north central United States. Reg. Environ. Change, 19, 1187-1199, https://doi.org/10.1007/ s10113-019-01474-y.

Yu, L., S. Zhong, J. Winkler, D. Doubler, X. Bian, and C. Walters, 2017: The inter-annual variability of southerly low-level jets in North America. Int. J. Climatol., 37, 343-357, https:// doi.org/10.1002/joc. 4708 . 